\title{
Modalita u Janáčka z pohledu českých a slovenských muzikologů
}

\section{Janáček's Modality from the Point of View of Czech and Slovak Musicologists}

\author{
Karel Steinmetz / karel.steinmetz@osu.cz \\ Department of Music Education, Faculty of Education, University of Ostrava, CZ
}

\begin{abstract}
In his study the author observes how several Czech and Slovak musicologists since 1950s paid attention to this distinct phenomenon in Janáček's music, i.e. modality. These are represented maily by Jiř́ Vysloužil at the prominent Janáček congress in Brno in 1958 and subsequently in the article published by Hudební rozhledy "Modální struktury u Janáčka" (Janáček's Modal Structures), later by Jaroslav Volek and his significant studies "Modalita a flexibilní diatonika u Janáčka a Bartóka" (Modality and Flexible Diatonicism in the Music by Janáček and Bartók) and "Modalita a její formy z hlediska hudební teorie" (Modality and its Forms in the Perspective of Music Theory). Volek was followed by further authors considering modality from the point of view of music theory (Risinger, Smolka, Tichý) and studying modality in the works by Leoš Janáček; also two speakers from abroad should be mentioned: C. L. Firca from Romania and Z. Helman from Poland. Then there are mainly Czech authors who refer to these problems at Janáček congresses in Brno in 1968, 1974, 1978 and then 1988 (that particular year was dedicated to the problems of modality). Also the contribution by Jan Trojan must not be forgotten. He specialized in tonality and harmony in Moravian folksong, i.e. phenomena that Janáček himself studied in his folkloristic treatises and that influenced so strongly his music thinking which tends to be more horizontal, melodic (this relates to the use of modal terrains that resist the hierarchization of individual degrees of the scale). Problems of Janáček's modality were also often discussed at the Ostrava conferences Janáčkiana. It was here that Jaroslav Volek, for instance, presented for the first time his new concept of modality as early as 1978, 1979 and 1981. In the first decades of the 21st century in Ostrava there followed further papers on Janáček's modality, e.g. those by Leoš Faltus (2008), Roman Dykast, Markéta Štefková, Juraj Ruttkay (2010) and Zuzana Martináková (2016).
\end{abstract}

\section{Key words}

Leoš Janáček and his works, music folkloristics, Moravian folksong, modality, flexible diatonicism 
Leoš Janáček vytvořil vedle velkého množství kompozic, od drobných klavírních skladbiček po celovečerní opery, ${ }^{1}$ také významné dílo folkloristické a hudebně teoretické, souborně poprvé vydané v 50., 60., a 70. letech, ${ }^{2}$ a pak i spolu s dalším literárním dílem v rámci Souborného kritického vydání děl Leoše Janáčka na začátku tohoto století. ${ }^{3}$ V těchto svých statích se však Janáček vůbec nezmiňuje o typickém utváření melodiky (i harmonie v doprovodech hudců) v moravských lidových písních, které jsou předmětem jeho folkloristických prací, ale také ve svých skladbách - o modalitě, melodicko-harmonickém tvarování často tak příznačném právě pro Janáčkovu hudbu. Podle Jaroslava Volka „př́klady na modálni struktury lze u něho nalézt $v$ celých desitkách, snad $i$ stovkách, a to ve skladbách všech obsazeni a žánrů. "4 Ve svých folkloristických studiích ${ }^{5}$ Janáček nepíše samozřejmě o modalitě, ${ }^{6}$ ale užívá termínu s ní úzce souvisejícím: „diatonická diferenciace“ a pak „staré“ nebo „církevní tóniny“. Také janáčkovská literatura v padesátých i šedesátých letech minulého století uvádí v skladatelově díle pouze souvislost s mody historickými či s těmi, co se uplatňují v hudbě folklorní. ${ }^{7}$

Přímo o modálních strukturách v Janáčkově hudbě se poprvé zmiňuje až Jiří Vysloužil. Ten v letech 1954 až 1957 věnoval mimořádnou pozornost lidové písni na Moravě a ve Slezsku ${ }^{8}$ a tehdy zároveň připravoval k tisku výše zmíněné vydání všech Janáčkových folkloristických studií, ${ }^{9} \mathrm{v}$ nichž mnohé poznatky ze studia moravské lidové písně pak spojil s Janáčkovými názory v jeho folkloristických pracích. Pak o tom referoval v roce 1958 na velkém brněnském mezinárodním kongresu ${ }^{10}$ a později psal v Hudebních rozhledech v článku Modálni struktury u Janácka. ${ }^{11}$ Zde si Vysloužil všímá, jak Janáček porušuje

1 Katalog Janáčeks' Works. A catalogue of the music and writings of Leoš Janáček autorů SIMEONE, Nigel, TYRRELL, John, NĚMCOVÁ, Alena uvádí na 160 dokončených děl.

2 Srov. VYSLOUŽIL, Jiří (ed.). Leoš Janáček: O lidové písni a lidové hudbě (dokumenty a studie). Praha: Státní nakladatelství krásné literatury, hudby a umění, 1955; BLAŽEK, Zdeněk (ed). Leoš Janáček: Hudebně teoretické dílo 1 a 2. Praha: Supraphon, 1968 a 1974.

3 Leoš Janáček: Folkloristické dílo 1 a 2. Brno: Editio Janáček, 2009 a 2020; Leoš Janáček: Teoretické dílo 1 a 2. Brno: Editio Janáček, 2007 a 2007-2008; Leoš Janáček. Literární dílo 1 a 2, Brno: Editio Janáček, 2003.

4 VOLEK, Jaroslav. Modalita a flexibilní diatonika u Janáčka a Bartóka. In Československo-mad’arské vztahy v hudbě, Ostrava: Krajské kulturní středisko, 1982. s. 69.

5 Zvláště ve studiích Obraty melodické v lidové písni, O tónině v lidové písni a v 2. kapitolce stati O hudební stránce národní písně na Moravě nazvané Nápěv lidové písně. Nově in Leoš Janáček Folkloristické dílo 1. Brno: Editio Janáček, 2009, s. 57-63, 355-368 a 158-208.

6 Pojem modalita vázaný na vztahy melodické a akordické či harmonické nemohl Janáček samozřejmě znát, nebot se ustavoval v muzikologii jen pozvolna, spíše až v druhé polovině 20. století. Srov. heslo „modalita“ ve Slovníku české hudební kultury, Praha: Editio Supraphon, 1997, s. 559-561.

7 Např. PODÉŠŤ, Ludvík. O harmonické práci ve sborové tvorbě Leoše Janáčka. Hudebni rozhledy X, 1957, s. 138, VOGEL, Jaroslav. Leoš Janáček. Život a dílo. Praha: Státní hudební vydavatelství, 1963, např. s. 137.

8 VYSLOUŽIL, Jiří. Lidová píseñ na Moravě a ve Slezsku. Brno, 1957 - strojopis, 3 svazky - 811 stran.

9 Viz v pozn. 2 uvedené vydání publikace Leoš Janáček: O lidové písni a lidové hudbě (dokumenty a studie). Praha: Státní nakladatelství krásné literatury, hudby a umění, 1955. Publikaci k vydání připravil a poznámkami opatřil dr. Jiří Vysloužil.

10 VYSLOUŽIL, Jiří. Janáčkova tvorba ve světle jeho hudebně folkloristické teorie. In. Leoš Janáček a soudobá hudba. Praha: Panton - Knižnice Hudebních rozhledů, 1963, s. 361-376.

11 VYSLOUŽIL, Jiří. Modální struktury u Janáčka. Hudebni rozhledy 19, 1966, č. 18, s. 552-555. 
„princip nadřazenosti harmonie melodii“, a to v chromatizování diatoniky zvláštními alteracemi a v nezvyklých melodických sledech, harmonických vazbách a charakteristických závěrových vzorcích, v nichž je citlivý tón snižován o půltón. Třeba tonální vztahy v Janáčkových skladbách sleduje Vysloužil v paralelách se všemi základními nápěvnými rysy moravského a slezského folkloru, jako byly nápěvné typy s „melodickou modulaci“ či nápěvy s dur-mollovou diatonikou apod. Všímá si, že charakteristické intervaly starých tónin Janáček pojímá jako alterace ${ }^{12}$ a pracuje s nimi zcela volně; v jeho skladbách pak nalezneme vedle všech známých typů moravských „lidových tónin“, jako jsou lydická, mixolydická, dorická, aiolská, mollová lydická, dur-mollová tónina, ale i tóniny v moravském a slezském folkloru se nevyskytující, jako frygická či celotónová pentatonika. Vysloužil pak upozorňuje, že Janáček v rozpravě Obraty melodickév lidové pisni píše o písních bohatýrského (rapsodického) slohu, které mají chromatický podklad, společný s veškerou moderní hudbou, čímž mínil všechny intervaly, vybrané lidovým tvůrcem smysluplně z dvanáctitónové množiny, přičemž vzniklé tónové řady podle něj nelze ztotožňovat se starými stupnicemi. Ve 2. kapitole s názvem Nápěv lidové pisně větší stati (předmluvy k vydání sbírky Bartoš III) O hudebni stránce národnich pisni moravských ${ }^{13}$ zavádí pro tonální určení „měnivých nápěvư“ pojem „zmocněný tón“, jímž nápěv začíná i končí nebo se k němu vrací anebo na něm nějaký čas zůstává. Je to zkrátka tón, který v nápěvu na sebe strhává největší pozornost a také nahrazuje do jisté míry funkční harmonické vztahy. ${ }^{14}$

Ve studii $O$ tónině v lidové pisni si Janáček všímá jmen tónin tvrdých (dur) s velkou tercií od základního tónu, měkkých (moll) s tercií malou a chromatických (barevných) s pưltónovou diferenciací. Janáček pokládá tonalitu za jeden zdroj krásna. Naopak ř́ká, že „bez tóniny neni hudby“. A také: „Lidová píseň nezná atonality“. Jak píše Jiří Vysloužil mnohem později v 2. části úvodu k vydání Folkloristického díla 1 Leoše Janáčka (2009, s. xviii), Janáček tím „reagoval odmitavě $i$ na jev, který hýbal moderni hudbou 20. stoleti.“” Naopak co spojuje Janáčka s ostatní hudební modernou, byly právě modální rysy jeho hudby, jak uvádí Vysloužil v závěru své studie Modální struktury u Janáčka. Vždyte i mnozí mladší skladatelé objevili na prahu minulého století ve folkloru další možnosti současného hudebního tvoření, Janáček však s modálními strukturami zacházel zcela svobodně (ve shodě s vlastním uměleckým cítěním), což ho právě odlišovalo „od těch skladateli̊, kteři se modality lidové písně drželi př́sně, se všemi jejími omezujicími i archaizujícími atributy. "15

Ve studiu melodiky a harmoniky v moravské lidové písni pak na Vysloužila v mnohém navázal Jan Trojan. Ten ve spisu Moravská lidová písen (melodika, harmonika) ${ }^{16}$ rozeznává z hlediska melodicko-harmonické složky lidových písní tř̌i vývojové fáze. Nejstarší nápěvy jsou založeny na neúplných stupnicových řadách, jejichž znaky jsou „kolísavé tóny“ a archaické nápěvné obraty (jedním z nejtypičtějších melodických obratů je tritón, který

12 Podle Jaroslava Volka o pưltón zvy̌šené či snížené tóny diatonické řady, tzv. „diatonické flexe“ či „kolísavé tóny" u Jana Trojana, nelze pojímat v modalitě jako alterace.

13 Nově v Leoš Janáček: Folkloristické dílo 1. Brno: Editio Janáček, 2009, s. 158-208.

14 Jak bude pojednáno později, dnes rozdíl mezi tonalitou a modalitou je mj. i v tom, že u tonality jsou tóny hierarchizovány centricky a u modality distančně.

15 VYSLOUŽIL, Jiří. Modální struktury u Janáčka. Hudebni rozhledy 19, 1966, č. 18, s. 555.

16 TROJAN, Jan. Moravská lidová píseñ (melodika harmonika). Praha: Editio Supraphon, 1980. 
později vstupuje do souvislosti s lydickou či mixolydickou tónovou řadou). Tyto neúplné řady (často tetrachordy evokující představu stupnicového výseku) nachází také Jozef Kresánek u nejstarších slovenských lidových písní. ${ }^{17}$ Druhé vývojové období Trojan vidí v písních modálního charakteru, přičemž mody, které se v nich vyskytují, se nekryjí s modálními strukturami církevních stupnic, což viděl i Janáček, jak bylo připomenuto níže. Jde totiž spíše o modální řady sui generis, blížící se pojmům Fa-modus, Re-modus apod. Třetí období je založeno na durové a mollové stupnicové řadě. Samozřejmě, že se jednotlivé typy prolínají, v čemž Trojan spatřuje jeden ze slohových znaků lidové písně. Stává se totiž, „že archaické nápěvné prvky prostupuji i modálni oblast a dostávaji se nejnovějši dur-mollové fáze. Ultradiatonické melodie, založené na pưsobnosti kolísavých stupňů, obsahuji i modálni prvky a dokonce $i$ dur - mollové. "18 Zatímco Vysloužil od samého počátku sledoval, jak se promítalo Janáčkovo studium lidové písně do jeho kompoziční praxe, Trojana více zaujalo to, co nového vnesl Janáček do etnografického a hudebně folkloristického bádání. ${ }^{19}$ Samozřejmě je v této materiálově bohaté a fundované monografii proveden obsáhlý výzkum melodiky a harmoniky moravské lidové písně, tedy to, s čím se Vysloužil vyrovnával ve spisu, který zůstal dosud v rukopisu. ${ }^{20}$ Trojan detailně popsal a analyzoval hlavní rysy hudební dikce moravské lidové písně, správně pochopil vzájemnou souvislost melodických (horizontálních) infrastruktur s harmonicko-akordickými vertikálami a ve své publikaci zavedl nové hudebně teoretické pojmy, např. „mixolydická“ a „lydická“ funkce - označuje je harmonickými značkami M a L - (a obecněji v širším pojetí je nazývá „funkcemi hudeckými“); ovšem pracuje také s Janáčkovým termínem „moravská modulace“21

17 KRESÁNEK, Jozef. Slovenská l'udová pieseñ zo stanoviska hudobného. Bratislava: Slovenská akadémia vied a umení, 1951.

18 Srov. TROJAN, Jan c.d., s. 205. Kolísavými tóny Trojan rozumí výskyt jediného tónu ve stupnicové řadě ve dvou podobách, v základní a zvýšené, případně snížené (Jaroslav Volek razil pro tento jev termín flexibilní diatonika - viz pozn. 28). Ultradiatonická soustava lidové písně s kolísavými tóny má pevný - neměnný základní tón, jenž nelze zvyšovat či snižovat a taktéž jeho dominantu (5. stupeň), na 2., 3., 4., 6. a 7. stupni se mohou vyskytovat v dur i moll kolísavé tóny. Od chromatické soustavy umělé hudby s alterovanými tóny se liší tím, že tato soustava má ještě navíc pevný tón, který nelze alterovat, a tím je ještě 3 . stupeň. Alterační soustava připouští alterační zvýšení či snížení 2. stupně v dur, u ultradiatoniky se projevuje pouze snížení. V systému kolísavých tónů není známo snížení 4. stupně v moll, zatímco v chromatické soustavě se snížení vyskytuje. Konečně poslední rozdíl mezi oběma soustavami je v nemožnosti (dle klasické teorie) alterovat - snižovat v dur 7. stupeň, zatímco v soustavě kolísavých tónů zcela běžná záležitost.

19 O tom, jak Janáček jedinečným zpo̊sobem využil jednoho ze základních znaků moravské nápěvnosti ve svém díle, totiž kolísavých tónů, přináší Trojan v citovaném díle na s. 29; je to pouze nápěvek hned v prvním taktu Balady blanické s kolísavým 4. stupněm („lydická v moll!““).

20 VYSLOUŽIL, Jiří. Lidová píseň na Moravě a ve Slezsku. Brno, 1957 - strojopis 3 svazky - 811 stran.

21 Toninové vybočení nápěvů z durové či mollové tóniny do durové tóniny sníženého VII. stupně. V závěru písně následuje návrat snížené septimy k základnímu tónu (např. z A dur do $\mathrm{E}$ dur a odtud do D dur; z této tóniny v závěru pak návrat do E dur). K termínu „moravská modulace“ se Trojan obšírně vrací ve stati O moravské modulaci. K jedinečnému hudebně folkloristickému termínu Leoše Janáčka. Opus musicum 21, 1989, č. 3, s. 65-72. Zde mimo jiné reaguje na Volkovu dřívější kritiku v referátu na konferenci Morava v české hudbě. 
či bartošovským „molezza dura“.22 Trojan oba tyto termíny v minulosti kritizované23 ovšem obhajuje. ${ }^{24}$

Na konci 70. let a začátkem let osmdesátých minulého století přišel se zásadními příspěvky o Janáčkově modalitě a modalitě vůbec estetik a hudební teoretik Jaroslav Volek. Nejprve to byly jeho dva referáty na ostravské konferenci Janáčkiana ${ }^{25}$ a pak v roce 1981 přednesl Volek na ostravské konferenci zásadní příspěvek Modalita a flexibilni diatonika u Janáčka a Bartóka. ${ }^{26}$ Před tím ale druhou, stejně významnou studii pojednávající o modalitě, tentokrát z pohledu hudebněteoretického publikoval Jaroslav Volek ve formě cyklostylované brožury (vydané Svazem českých skladatelů a koncertních umělců k 60 . narozeninám Karla Risingera). Je to zásadní pohled na modalitu podaný v přehledně uspořádaných a formulačně brilantních třiceti teorémech a šesti dodatcích. ${ }^{27}$ Volek zde používá Risingerových adjektiv „distanční“ a „centrická“, např. ve spojení se slovy hierarchie či struktura, ovšem při dodržení faktu, že distanční strukturnost jak v historickém vývoji, tak i čistě systémově předchází strukturnost centrickou. U modality - např́klad v církevních modech - je více dominantní hierarchie distanční, kdy při střídání modů (v melodické modulaci) zůstává stejná finalis či dominanta, tedy jakýsi „zmocněný tón“ (Janáčkův termín ${ }^{28}$ ), ale mění se distance intervalů v modu, zatímco při modulaci tonální

22 Spojení mollové tóniky s durovou subdominantou (ta bývá často přehodnocena na druhou dominantu z paralelní tvrdé tóniny); pak následuje kvintakord na přirozeném (sníženém) 7. stupni, který je nejčastěji přehodnocen na dominantu z tvrdé paralelní tóniny. Spoj „molezza dura“ působí jako přechod z původní mollové tóniny do tóniny durové paralely (např. z a moll do C dur: a moll, D dur, G dur, C dur).

23 Uved’me jako prvního kritika Janáčkova termínu „moravská modulace“ Emila Axmana v knize Morava v české hudbě XIX. století (Praha 1920); prý jde jen o modulační vybočení a modulací ve smyslu harmonickém to nelze nazvat. V případě termínu „molezza dura“, který Trojan převzal od Františka Bartoše, k tomu se kriticky stavěl např. Josef Stanislav v práci O lidové hudbě, písni a tanci, Praha 1958).

24 Jaroslav Volek v referátu na brněnské konferenci Morava v české hudbě v listopadu 1984 sice Trojanovu práci velice pochválil, leč vytýká ji, že ve více případech přisuzuje moravské lidové hudbě pro ni zcela specifické idiomy, které se však často vyskytují i u jiného druhu či žánru hudby nebo v hudebním folkloru jiných národů a hlavně, že zavádí nové termíny pro jevy, které lze uchopit jinými, v hudební teorii zavedenými pojmy. Srov. VOLEK, Jaroslav. Moravské hudební idiomy a hudební teorie. In Morava v české hudbě. Brno: Svaz českých skladatelů a koncertních umělců, 1985, s. 92-97. Trojan pak na tuto kritiku reaguje v článku O moravské modulaci (K jedinečnému termínu Leoše Janáčka (in Opus musicum 21, 1989, č. 3, s. 71-72).

25 Na 2. ročníku ostravské konference Janáčkiana s tématem Regionálně etnické podněty v díle Leoše Janáčka zazněl 1. 6. 1978 Volkův referát Janáček a kvalitativně nové zprisoby využití folkloru v hudbě 20. století a o rok později na 3. ročníku Janáčkian dne 29. 5. Nová teoretická koncepce modality a flexibilní diatoniky - Janáčkưv tvůrč́ prínos $k$ této problematice (oba referáty však ve sborníku Janáčkiana ' 78 a ' 79 chybí, jak je uvedeno v poznámce vydavatele (srov. Janáčkiana '78 a'79. Ostrava: Krajské kulturní středisko, 1980, s. 131). Volek referát na jarních Janáčkianech 1978 pak rozšířil a přednesl téhož roku na podzimním kolokviu Leoš Janáček a dnešek. Srov. Leoš Janáček und die neue Auswertung spontaner Elemente der musikalischen Kreativität im XX. Jahrhundert. In Colloquium Leoš Janáček ac tempora nostra. Brno: Česká hudební společnost, 1983, s, 41-75.

26 Jaroslav Volek původně pronesl tento referát v němčině na semináři Janáček - Bartók, který pořádalo Mad’arské kulturní středisko v Praze ve spolupráci s Českou hudební společností ve dnech 27. a 28. 2. 1980. Jeho českou verzi rozmnožil, jako podklad pro diskusi na chystaném semináři Svaz českých skladatelů a koncertních umělců, ale tiskem vyšla až ve sborníku referátů z ostravské konference o tři roky později - srov. Československo-mad'arské vztahy v hudbě. Ostrava: Krajské kulturní středisko, 1982, s. 68-95.

27 V rozššřrené podobě tuto studii s názvem Modalita a její formy z hlediska hudební teorie pak Volek zařadil do souboru svých teoretických prací Struktura a osobnosti hudby. Praha: Panton, 1988, s. 8-69.

28 Podle Janáčka je to tón, jímž nápěv začíná i končí nebo se k němu vrací anebo na něm nějaký čas zůstává; 
(samozřejmě u tónin stejné jakosti) se mění základní tón a nemění se intervaly, což vidíme v případě centrické hierarchie. Ovšem i u modů nelze striktně mluvit (způsobem ano - ne) o opozici hierarchické - nehierarchické, ale spíše o více či méně hierarchické, což znamená, že ze dvou komparovaných modů je jeden více (a to nejen distančně, ale hlavně centricky) organizován a jiný méně. Ačkoliv se Volek omezuje v této tématice hlavně na melodické tvary, neznamená to, že by se „kompetence“ modality nevztahovala též na oblast akordiky, harmonie. Akordickou i harmonickou modalitu však považuje za sekundární a z melodiky odvozenou záležitost (u modální akordiky se akordy k melodice stejného typu vytvářejí jaksi „v druhém plánu“). Volek pak zcela systematicky třídí a klasifikuje mody podle jejich intervalové struktury, ambitu a počtu tónů v modu, tedy jeho objemu, kde je nutná vazba na sedmidílnou gradualitu oktávy (menší objem modu než je sedm tónů přináší jakousi nenaplněnou stupňovitost a tedy útvary s vynechanými stupni). V této studii je také teoreticky vysvětlen zásadní Volkův objev, totiž „flexibilní diatonika“29, respektive „diatonická flexe“, o kterém Volek psal či referoval na konferencích už dříve, ${ }^{30}$ nejvíce však v již vzpomenuté stati Modalita a flexibilní diatonika u Janácka a Bartóka, ve které dokládá výskyt tohoto jevu právě u Leoše Janáčka a Bély Bartóka.

Vedle Volkovy koncepce modality, kterou akceptovali a rozvíjeli další muzikologové, ${ }^{31}$ zkoumali modalitu i pražští hudební teoretici, vycházející ale více z názorů Karla Janečka $^{32}$ a také František Řehánek. Ten se však věnoval ve svých pracích zvláště harmonické-

je to tón, který na sebe v nápěvu strhává největší pozornost a také nahrazuje do jisté míry funkční harmonické vztahy.

29 Termín flexibilní diatonika (též diatonická flexe) zavedl do hudebně teoretické terminologie Jaroslav Volek pro nahrazení jednoho tónu diatonického modu jiným, rovněž diatonickým tónem, ale o půl tónu vyšším nebo nižším (srov. s poznámkou 12).

30 Ve studiích a referátech na konferencích v Ostravě a Brně např. Nová teoretická koncepce modality a flexibilni diatoniky - Janáčkưv tviorči př́nos $k$ této problematice či Leoš Janáček a nový zprisob využití proků spontánní hudebni tvoŕivosti v hudbě 20. století.

31 Např. Jiří Fukač a Miloš Štědroň ve stati Modalita, flexibilita a vývoj hudebního strukturování (ve sborníku vydaném Svazem českých skladatelů a koncertních umělců, 1984, s. 47-69 či sám Miloš Štědroň ve více studiích, z nichž uved’me jen článek Janáčkova melodika - některé specifické rysy. In Sbornik praci Filozofické fakulty brněnské university H 30, 1995, s. 93-108.

32 V problematice modality se vedle brněnských autorů Vysloužila, Trojana, pak Fukače a M. Štědroně uplatňují zvl. hudební teoretici z Akademie múzických umění v Praze Karel Janeček, Karel Risinger, Jaroslav Smolka a Vladimír Tichý. Risinger směřuje k problematice modality skrze svou koncepci distanční a centrické hierarchie (Hierarchie hudebních celků /1969/), v Nauce o harmonii XX. století / 1978/ a přistupuje k modalitě na vertikálním základě. V referátu na brněnském kongresu Hudba slovanských národů Modalita v české moderní hudební teorii vidí největší rozdíl mezi modalitou a tonalitou v tom, že v modální tónové řadě není určeno tonální centrum. Z této Risingerovy koncepce pak vychází Jaroslav Smolka ve studii Utajená modalita (Živá hudba IX. Praha: Státní pedagogické nakladatelství 1986, s. 97-121) a hlavně Vladimír Tichý v rozsáhlé stati Modalita /Systematika/ (in Živá hudba VIII. Praha: Státní hudební vydavatelství, 1984, s. 117-191. V závěru své stati Tichý sleduje tři zpo̊soby organizace tónových výšek - modalitu, tonalitu a serialitu a uvádí: „Hledisko modality je výrazně hlediskem výbèru tónového materiálu [...], resp. distančni hierarchie v intervalovém uspořádáni tónových výšek. [...] Zkoumáme-li strukturu jako tonálni, hledáme centrum a všímáme si funkčních vztahủ ostatniho materiálu k tomuto centru. Otázka výběru tónů (tónové množiny) stoji stranou našeho zájmu. " Jako současný teoretik ovšem počítá i s hlediskem pořadí tónových výšek uspořádaných na základě dané řady (série) v časovém průběhu, tedy s hlediskem seriality. Pak vzájemný vztah modality, tonality a seriality - tří různých zposobů organizace tónových výšek vidí jako tři protínající se kružnice, vymezující celkem sedm polí, z nichž tři jsou pole čisté modality či čisté tonality nebo čisté seriality a ostatní jsou kombinace v podobě např. „tonalizace 
mu myšlení tohoto českého skladatele, ${ }^{33}$ ale později i diatonickým modům u Leoše Janáčka. ${ }^{34}$ Přestože zde Řehánek mluví o diatonických modech a vidí, že Janáček byl ve své tvorbě ovlivněn modálním bohatstvím lidových písní východního typu, často vysvětluje tóny o půltón zvýšené či snížené nikoliv na základě vedení modální melodie s charakteristickými intervaly (dórská sexta, lydická kvarta apod.), ale jako tóny alterované. V harmonii je často označuje velmi složitými „funkčními“ značkami (což vycházelo z původního Řehánkova zájmu) a vůbec přitom nebere v úvahu existenci tzv. „zahuštovacích tónů““. ${ }^{35}$ V̌̌e chápe čistě harmonicky ve vertikálách, zatímco hudební myšlení Janáčkovo více preferovalo horizontálnost jak v melodice, tak v rytmice (ve sčasování) a konečně i v tektonice (např. exponováním dvou či více disparátních vrstev).

Problematika modality v díle Leoše Janáčka byla řešena několikrát účastníky ostravských hudebněvědných konferencí Janáčkiana. Tak např. Jaroslav Volek již v letech 1978, 1979, 1981 zde pronesl tři referáty, v nichž seznamoval muzikologickou veřejnost se svou koncepcí modality v díle Leoše Janáčka. ${ }^{36}$ Později, až v novém tisíciletí, se na těchto ostravských konferencích dotkli sledované problematiky i další čeští a slovenští muzikologové. V roce 2008 to byl např. Leoš Faltus, který polemizoval s názory Františka Řehánka, jenž chápal všechny příklady uvedené v práci Harmonické myšleni Leoše Janáčka čistě harmonicky ve vertikálách, zatímco převažujícím způsobem Janáčkova vyjadřování bylo myšlení horizontální (melodické), často s využitím modality. Ve sborníku z 30. ročníku ostravských Janáčkian 2010 Moravsko-slovenské folklorni inspirace v české a slovenské hudbě

modality“ či naopak „modalizace tonality“, kdy třeba každý modus umožňuje vznik tónového centra a podobně. Ovšem zcela vyčerpávající pohled na modalitu podal - jak bylo výše uvedeno - Jaroslav Volek. V nejnovější době se vedle těchto „zvučných jmen“ českých muzikologů a hudebních teoretiků zařadila pojednáním o modalitě i absolventka Ústavu hudební vědy Filozofické fakulty Masarykovy univerzity Klára Hedvika Mühlová, a to svou diplomovou prací Modalita - proměny, posun a vývoj paradigmat pohledem změn východisek teoretických reflexi v českém prostředí (Brno 2016) či před ní Miloš Zapletal v doktorské disertaci a z ní pak vycházejících časopiseckých studiích, jako např. Horňácké lidové písně z pohledu modality a flexibilní diatoniky. Opus musicum 2012, roč. 44, č. 5, s. 22-40.

33 Řehánkovy studie o Janáčkově harmonii a tonalitě vycházejí z jeho práce diplomní (Janáčkovo učeni o harmonii, strojopis Brno 1965/) a pak i rigorózní (Harmonické myšlení Leoš Janácka, strojopis, 1993, 443 s.). Byly to studie: Janáčkův přínos pro nauku o harmonii. Opus musicum, 1970, roč. 2, č. 1, s 9-11, Janáček a tonalita. In Colloquium Leoš Janáček ac tempora nostra. Brno: Janáčkova společnost, 1983, s. 279-287 a O harmonickém myšlení Leoše Janáčka. Hudebni věda, 2002, roč. 39, č. 1, s. 67-70.

34 ŘEHÁNEK, František. Modality in Janáček's Music Theory. Colloquium: Probleme der Modalität - Leoš Janáček heute und morgen, Brno: Filozofická fakulta MU, 1994, s. 179-185. TÝŽ. Diatonické mody Leoše Janáčka. Hudebni věda 40, 2003, č. 1, s. 29-69.

35 Podle Janáčka - jak je uvedeno ve 2. vydání jeho Úplné nauky o harmonii - mohou být kvintakordy, septakordy, nonové akordy apod. zahuštěny dalšími tóny diatonické stupnice, které ale nepatří k akordu, aniž by se změnil hudební význam akordu, aniž by se změnila jeho původní harmonická funkce; akord se však mění jako zvuk, tedy „sónicky“. Srov. VOLEK, Jaroslav. O zahuštování akordů. In Struktura a osobnosti hudby. Praha: Panton, 1988, s. 103-112.

36 Na 2. ročníku této konference s tématem Regionálně etnické podněty v díle Leoše Janáčka zazněl 1.6 .1978 Volkův referát Janáček a kvalitativně nové způsoby využití folkloru v hudbě 20. století a o rok později dne 29.5. 1979 Nová teoretická koncepce modality a flexibilní diatoniky - Janáčkưv tvưrči př́nos k této problematice. V roce 1981 (2. 6.) zde Volek přednesl referát s názvem Modalita a flexibilni diatonika u Janácka a Bartóka. Volkovy příspěvky plné nových a do problematiky modality přinášející skutečně objevné pohledy však nebyly do konferenčního sborníku zařazeny, nebot Volek je chtěl publikovat na jiném místě. Až referát v roce 1981 vyšel ve sborníku Československo-mad'arské vztahy v hudbě. Ostrava: Krajské kulturní středisko, 1982, s. 68-95. 
byly otištěny třri referáty tematicky zaměřené $\mathrm{k}$ námi sledované problematice. Markéta Štefková v příspěvku Vplyvy folklórnej „modality“ na hudobné myslenie Leoša Janáčka se soustředila na objasnění modality v moravských a slovenských lidových písních ve vztahu k Janáčkovu hudebnímu myšlení. V návaznosti na Jozefa Kresánka a jeho názorů na tonální podstatu archaických lidových písní dochází k názoru, že tonální a harmonické zvláštnosti, především princip tzv. „moravské modulace“, jsou vysvětlitelné jako specifický způsob využití dispozic, které Janáček odhalil prostřednictvím svého studia tonality lidových písní a stylu hudecké hry. Juraj Ruttkay v referátu Modalita a tonalita ako dva principy kompozičného myslenia vo vzt’ahu $k$ folklórnej hudobnej kultúre sledoval modalitu proti tradiční funkčně ukotvené dur-mollové tonalitě obohacené o enharmonické, chromatické a alterované operace, vedoucí až k extrémní totální organizaci dvanácti prvků chromatiky v systému dodekafonie a postwebernovského serialismu. Bohužel o modalitě v díle Leoše Janáčka toho v tomto široce koncipovaném př́ispěvku nebylo mnoho. Zato Roman Dykast v referátu Modalita a rytmus jako základ Janáčkova výrazového principu ${ }^{37}$ si všímá, jak Janáček v 1. smyčcovém kvartetu využívá svých pozoruhodných poznatků z oblasti hudební teorie a folkloristiky (např. mélický a sčasovací tvar motivů, kdy skladatel v různých variantách stahuje či rozšiřuje intervaly i délky tónů, čímž dochází k rychlému stř́íání různých modálních úseků). Dykast vidí že „ve spojeni se specifickou teorii melodických disonancí, které použivá jako zhuštovaci tóny v akordu, a s výrazovým uplatněním své „nauky o sčasováni“, umožnila Janáćkovi všechny tyto inovace mélicko-rytmického materiálu, potlačeni harmonické složky ve prospěch melodické [...] právě nová , umělá modalita. ${ }^{38}$ Konečně v roce 2016 referovala na ostravských Janáčkianech o modálních principech v Janáčkově tvorbě Zuzana Martináková. Také ona na základě vybraných příkladů z Janáčkových děl ukazuje, že v jeho kompoziční řeči převládají modální principy.

Tento příspěvek uzavíráme konstatováním, že v Janáčkově díle tak často se vyskytující modální struktury a modalita vůbec, k níž se skladatel dopracoval studováním melodiky (i harmoniky v případě doprovázejících hudců) moravské lidové písně, byly jedním z významných fenoménů, které přispěly k originalitě jeho hudby.

\section{Bibliography}

DYKAST, Roman. Modalita a rytmus jako základ Janáčkova výrazového principu v Janáčkově 1. smyčcovém kvartetu. Živá hudba 13 (2003), s. 69-79. Také In Moravsko-slovenské folklorni inspirace v české a slovenské hudbě (Janáčkiana 2010). Ostrava: Ostravská univerzita - Pedagogická fakulta, 2010, s. 67-74.

FALTUS, Leoš. František Řehánek: Harmonické myšlení Leoše Janáčka. Poznámky k rukopisu. In Leoš Janáček světový a regionální. Ostrava: Ostravská univerzita - Pedagogická fakulta, 2008, s. 139-172.

37 DYKAST, Roman. Modalita a rytmus jako základ Janáčkova výrazového principu. In Moravsko-slovenské folklorní inspirace v české a slovenské hudbě (Janáckiana 2010). Ostrava: Ostravská univerzita - Pedagogická fakulta, 2010, s. 68-73.

38 Tamtéž, s. 73. 
JANÁČEK, Leoš. Folkloristické dílo 1. Brno: Editio Janáček, 2009.

JANÁČEK, Leoš. Folkloristické dílo 2. Brno: Editio Janáček, 2020.

MARTINÁKOVÁ, Zuzana. Modálný princíp v Janáčkově tvorbe. In Janáčkiana 2016. Ostrava: Ostravská univerzita - Pedagogická fakulta, 2017, s. 75-85.

MÛHHLOVÁ, Klára Hedvika. Modalita - proměny, posun a vývoj paradigmat pohledem změn východisek teoretických reflexí v českém prostředí. Diplomová práce FF MU Brno: 2016.

RISINGER, Karel. Modalita v české moderní hudební teorii. In Hudba slovanských národů. Brno: Česká hudební společnost, 1981, s. 519-522.

RUTTKAY, Juraj. Modalita a tonalita jako dva principy kompozičního myslenia vo vztahu k folklórnej hudobnej kulture. In Moravsko-slovenské folklorní inspirace v české a slovenské hudbě (Janáčkiana 2010). Ostrava: Ostravská univerzita - Pedagogická fakulta, 2010, s. 59-66.

ŘEHÁNEK, František. Diatonické mody u Leoše Janáčka. Hudebni věda, 2003, roč. 40, č. 1, s. 2969.

SMOLKA Jaroslav. Utajená modalita. In Živá hudba IX: sbornik prací hudebni fakulty AMU. Praha: Státní pedagogické nakladatelství, 1986.

ŠTEFKOVÁ, Markéta. Vplyvy folklórnej „modality“ na hudobné myslenie Leoše Janáčka. In Moravsko-slovenské folklorni inspirace v české a slovenské hudbě (Janáckiana 2010). Ostrava: Ostravská univerzita - Pedagogická fakulta, 2010, s. 41-57.

ŠTĚDROŇ, Miloš. K problému kvartové melodiky a harmonie u Leoše Janáčka. Hudebni rozhledy, 1965 , roč. 18 , č. 1 , s. $7-10$.

ŠTĚDROŇ, Miloš. Janáčkovské podněty v soudobých moravských kompozičních technikách. Opus musicum, 1974, roč. 6, č. 5-6, s. 149-152.

ŠTĚDROŇ, Miloš. Janáčkova melodika - některé specifické rysy. In Sbornik praci Filozofické fakulty brněnské university H 30, 1995, s. 93-108.

TICHÝ, Vladimír: Modalita: systematika. In Živá hudba V: sbornik praci hudebni fakulty AMU. Praha: Státní pedagogické nakladatelství, 1984, s. 117-191.

TROJAN, Jan. Moravská lidová píseñ: melodika harmonika. 1. vyd. Praha: Editio Supraphon, 1980.

VOLEK, Jaroslav. Modalita a flexibilní diatonika u Janáčka a Bartóka. In Československo-mad’arské vztahy v hudbě (Janáčkiána 1981). Ostrava: Krajské kulturní středisko, 1982, s. 68-95; přetištěno In Struktura a osobnosti hudby. 1. vyd. Praha: Panton,1988, s. 199-223.

VOLEK, Jaroslav. Modalita a její formy z hlediska hudební teorie. In Struktura a osobnosti hudby. Praha: Panton,1988, s. 8-69.

VYSLOUŽIL, Jiřri (ed.). Leoš Janáček: o lidové pisni a lidové hudbě: dokumenty a studie. Praha: Státní nakladatelství krásné literatury, hudby a umění, 1955.

VYSLOUŽIL, Jiří. Lidová píseñ na Moravě a ve Slezsku. Brno, 1957 - strojopis, 3 sv. - 811 s.

VYSLOUŽIL, Jiří. Janáčkova tvorba ve světle jeho hudebně folkloristické teorie. In Leoš Janáček a soudobá hudba. Praha: Panton - Knižnice Hudebních rozhledů, 1963, s. 361-376.

VYSLOUŽIL, Jiří. Modální struktury u Janáčka. In Hudebni rozhledy, 1966, roč. 19, č. 18, s. 552-555.

ZAPLETAL, Miloš. Horňácké lidové písně z pohledu modality a flexibilní diatoniky. Opus musicum, 2012, roč. 44, č. 5, s. 22-40. 
